\title{
Phenotypic expression in familial adenomatous polyposis: partial prediction by mutation analysis
}

\author{
K P Nugent, R K S Phillips, S V Hodgson, S Cottrell, J Smith-Ravin, K Pack, \\ W F Bodmer
}

\begin{abstract}
The phenotypic expression in familial adenomatous polyposis (FAP) is variable. This study compares the phenotype of 27 patients with an identical 5 base pair (bp) deletion at codon 1309 with a group of 61 matched patients with FAP where knowledge of specific mutations is not available and with seven other different mutations in 24 subjects. Patients with the codon 1309 deletion have significantly more colorectal polyps at the time of colectomy than age and sex matched FAP controls $(p=0 \cdot 0001)$. The median number of polyps in colectomy specimens of patients with the deletion at codon 1309 was 4000 (interquartile (IQ) range 3000-4875), compared with 600 (IQ range 488-1400) in the matched controls. Mutations at codon 1323, 1407, and 233 were also associated with large numbers of polyps. Desmoid disease and extracolonic cancers were more common with the mutation at codon $1309(p=0 \cdot 003)$. In conclusion, there may be a correlation between a specific germline mutation and the number of large bowel polyps. There is residual heterogeneity in phenotypic expression, however, and this may result from the influence of other genes, specific environmental factors or chance.

(Gut 1994; 35: 1622-1623)
\end{abstract}

Patient phenotype in familial adenomatous polyposis (FAP) varies in the number of colorectal polyps and the presence or absence of a variety of extracolonic manifestations. Specific germline deletions within the coding sequence of the APC gene ${ }^{12}$ may explain some of this heterogeneity.

The coding region of the APC gene, on chromosome $5 \mathrm{q} 21$, is contained within 15 exons. Miyoshi et al ${ }^{1}$ analysed the mutations in 53 FAP patients and found that 23 were point mutations and 30 were associated with frameshifts resulting from deletions (28 cases) or insertions ( 2 cases). Exon 15 is the largest individual exon ( 6571 base pairs) containing codons 653 to $2843 ; 68 \%$ of the total mutations were clustered on exon 15 between codons 713 and 1597. The commonest mutation was a 5 base pair deletion at codon 1309 occurring in 10 of 53 patients $(19 \%)$. This study compares the phenotype associated with this mutation with those of other mutations.

\section{Methods}

The phenotype of 27 members from seven different families with an identical 5 base pair (bp) deletion at codon 1309 has been compared with: (a) a group of 61 age and sex matched patients with FAP where knowledge of specific mutations is not available and (b) seven other different mutations in 24 subjects.

The number of colonic adenomas at the time of colectomy was derived either by direct counting, where the number was low, or by extrapolation according to the surface area of the excised colon and the polyp count $/ \mathrm{cm}^{2}$ at a number of sites.

Information on upper gastrointestinal polyps has been collected prospectively. ${ }^{3}$ Clinically apparent desmoids and extracolonic carcinomas are known, as is parental history. Information on epidermoid cysts, osteomas, and congenital hypertrophy of the retinal pigment epithelium is incomplete and has not been included.

\section{Results}

Patients with codon 1309 deletion have significantly more colorectal polyps at the time of colectomy than the 61 age and sex matched FAP patients with unknown mutations $(p=0.0001$, Mann-Whitney $U$ test) (Table). The median number of polyps in their

\section{London}

K P Nugent

R K S Phillips

$S$ V Hodgson

\section{Imperial Cancer}

Research Fund,

Lincolns Inn Field, London

R K S Phillips

S V Hodgson

$S$ Cottrell

J Smith-Ravin

K Pack

W F Bodmer

Correspondence to: Mr R K S Phillips, St Mark's Hospital, City Road, London EC1V 2PS

Accepted for publication 11 March 1993

\begin{tabular}{|c|c|c|c|c|c|}
\hline Deletion & $\begin{array}{l}\text { Patients } \\
\text { (n) }\end{array}$ & $\begin{array}{l}\text { Desmoid } \\
(n)(\%)\end{array}$ & $\begin{array}{l}\text { Colon polyps } \\
\text { (median no) }\end{array}$ & $\begin{array}{l}\text { Duodenal polyps } \\
\text { (median no) (age) }\end{array}$ & $\begin{array}{l}\text { Other cancers } \\
\text { (no of patients) }\end{array}$ \\
\hline 5 bp Deletion at codon 1309 & 27 & $8(30)$ & 4000 & $20(51)$ & \multirow{9}{*}{$\begin{array}{l}3 \text { Upper gastrointestinal } \\
4 \text { Rectal } \\
1 \text { Testicular } \\
1 \text { Thyroid } \\
1 \text { Renal (6) } \\
1 \text { Upper gastrointestinal (1) } \\
1 \text { Ileostomy (1) } \\
1 \text { Bladder (1) } \\
1 \text { Thyroid (1) }\end{array}$} \\
\hline Unknown & 61 & $7(11)$ & 600 & $13(48)$ & \\
\hline $5 \mathrm{bp}$ Deletion at codon 1061 & 7 & $1(14)$ & 800 & $15(51)$ & \\
\hline $1 \mathrm{bp}$ Insertion at codon 1204 & 6 & $0(0)$ & 500 & $10(50)$ & \\
\hline $1 \mathrm{bp}$ Insertion at codon 1407 & 3 & $1(33)$ & 3500 & $4(34)$ & \\
\hline $1 \mathrm{bp}$ Insertion at codon 764 & 2 & $1(50)$ & 288 & & \\
\hline $1 \mathrm{bp}$ Insertion at codon 1323 & 1 & $0(0)$ & 2790 & & \\
\hline $1 \mathrm{bp}$ Insertion at codon 969 & 1 & $0(0)$ & 300 & $20(35)$ & \\
\hline 1 bp Substitution at codon 233 & 4 & $0(0)$ & 3025 & $5(39)$ & \\
\hline
\end{tabular}


colectomy specimens was 4000 (interquartile (IQ) range 3000-4875), compared with 600 (IQ range 488-1400) in the 61 matched patients.

Colon polyps were also numerous with a $1 \mathrm{bp}$ insertion at codon 1323 or a $1 \mathrm{bp}$ deletion at 1407, and when there was a 1 bp substitution (resulting in a stop codon) at codon 233. Other mutations were associated with far fewer colonic polyps.

There was an apparent excess of desmoid tumours when there was a 5 bp deletion at codon 1309; closer examination, however, shows one family of 12 members with sufficient risk factors, including multiple surgery and pregnancies, had no desmoid disease. Extracolonic cancers were also common with the mutation at codon $1309 \quad(p=0.003$, Fisher's exact test).

\section{Discussion}

Nagase et al $^{4}$ suggested that truncation of the APC gene product in the region of the deletion between codon 1255 and codon 1467 (which results in a premature stop codon downstream from the deletion by frame shift) results in a profuse type of polyposis. Patients in this study with deletions between these two codons similarly have a high polyp density, as do four family members with a 1 bp substitution at codon 233 . Colonic polyp count clearly shows a bimodal distribution not consistent with any particular region of the APC gene and the conclusion made by Nagase et al seems over simplified.

The presence of other phenotypic expressions varies between patients with the same mutation. Upper gastrointestinal polyps do not seem more frequent when there is a deletion between codons 1255 and 1467, and desmoid disease is similarly variable. Although there was an apparent excess of demoid disease within the seven families with a 5 bp deletion at codon 1309 , only one of 12 patients within one of the families had desmoid disease. This family may be less susceptible to desmoid disease because of a protective modifier locus cosegregating within this family. Other extracolonic malignancies also seem particularly frequent at codon 1309.

These findings suggest that there may be a correlation between a specific germline mutation and the number of large bowel polyps. Phenotypic expression in patients with the same mutation varies, however, therefore not all clinical variation is caused by a particular APC gene mutation. The residual heterogeneity in phenotypic expression may be influenced by other genes, specific environmental factors or chance.

We would like to thank the Polyposis Registry at St Mark's Hospital for their help in supplying patients for this study.

1 Miyoshi Y, Ando H, Nagase H, Nishisho I, Horii A, Miki Y, et al. Germ-line mutations of the APC gene in 53 familial adenomatous polyposis patients. Proc Natl Acad Sci USA 1992; 89: 4452-6.

2 Cottrell S, Bicknell D, Kaklamanis L, Bodmer W. Molecular analysis of APC mutations in familial adenomatous polyposis and sporadic colon carcinomas. Lancet 1992; 340: 626-30.

3 Spigelman AD, Williams CB, Talbot IC, Domizio P, Phillips RKS. Upper gastrointestinal cancer in patients with familial adenomatous polyposis. Lancet 1989; ii: 783-5.

4 Nagase H, Miyoshi Y, Horii A, Aoki T, Ogawa M, Utsunomiya $\mathrm{J}$, et al. Correlation between the location of germ-like mutations in the APC gene and the number of colorectal polyps in familial adenomatous polyposis patients. Cancer Res 1992; 52: 4055-7. 